\title{
SENTIDOS ALEGÓRICOS NA CONSTRUÇÃO DOS ESPAÇOS ANTAGONISTAS: CENTRO, EM A CAVERNA, DE JOSÉ SARAMAGO, E A ZONA FRANCA DE MANAUS, EM A CALIGRAFIA DE DEUS, DE MÁRCIO SOUZA
}

\section{ALEGORIC SENSES IN THE CONSTRUCTION OF ANTAGONIST SPACES: CENTER, IN A CAVERNA, BY JOSÉ SARAMAGO, AND ZONA FRANCA DE MANAUS, IN A CALIGRAFIA DE DEUS, BY MÁRCIO SOUZA}

\author{
Mariana Vieira Cardoso ${ }^{1}$ \\ Allison Leão ${ }^{2}$
}

Resumo: Em A caverna, de Saramago, a alegoria do Centro provoca o sofrimento do protagonista, cuja força de trabalho é inutilizada em um universo capitalista no qual o mercado dita regras de aceitação e inserção do humano. Analogamente, em A Caligrafia de Deus, de Márcio Souza, há inutilização da mão de obra e marginalização ocasionadas pelo advento da Zona Franca. Propomos o diálogo dessas obras como veículos de representações históricas que refletem os questionamentos da modernidade especialmente na relação entre memória e trabalho. Nesse sentido, são alegóricas, na expressão benjaminiana, revestindo-se do elemento narrativo e representando o declínio da humanidade.

Palavras-chave: Ficção e História; Alegoria; Memória; José Saramago; Márcio Souza.

Abstract: In A caverna, by Saramago, the allegory of the Center causes the suffering of the protagonist, whose work force is destroyed in a capitalist universe in which the market dictates rules the human acceptance and insertion. Similarly, in A caligrafia de Deus, by Márcio Souza, the worker is rendered unusable and marginalized by the advent of the "Zona Franca de Manaus". We propose the dialogue of these works as vehicles of historical representations that reflects the questions of modernity especially between memory and work. In this sense they are allegorical, in the Benjamin's expression, clothed with the narrative element and representing the decline of humanity.

Key words: Fiction and History; Allegory; Memory; José Saramago; Márcio Souza.

\section{Introdução}

Walter Benjamin (1984), aponta que a escrita é a ferramenta capaz de construir sentidos alegóricos que deverão ser desenvolvidos a partir dela, não somente como uma

\footnotetext{
${ }^{1}$ Licenciada em Letras pela Universidade do Estado do Amazonas, mestranda do Programa de Pós-Graduação em Letras e Artes (PPGLA-UEA), bolsista FAPEAM, e neste trabalho recebeu o apoio da Capes (PROCAD). E-mail: marianavicardoso@gmail.com

${ }^{2}$ Doutor em Letras pela UFMG (2008) e Professor Associado da Universidade do Estado do Amazonas (UEA). allisonleao@uea.edu.br
} 
simples imagem ou mote artístico, mas também como uma exposição moderna da história. Sob esta perspectiva, apontamos que se a escrita é visualizada como ferramenta dos sentidos alegóricos, o espaço - e por vezes a temporalidade - são os símbolos da alegoria construída. A pensínsula ibérica transformada em jangada por Saramago, os moinhos que cercam o universo maravilhoso de Dom Quixote, a terceira margem que contribui na construção estética da narrativa de Guimarães Rosa, além da Casa Verde em O alienista, de Machado de Assis, que demarca não apenas um movimento espacial mas, sobretudo, o movimento de um ideário. São muitos os exemplos que estampam o processo criativo espacial como sentido alegórico. O Cortiço, de Aluísio de Azevedo, ilustra, por exemplo, a formação de uma espacialidade social que constitui o processo de urbanização brasileira e a subjetividade de seus habitantes. Por vezes, este espaço alegórico funciona sob o paradigma do antagonismo, por exemplo, em Vidas Secas, de Graciliano Ramos ou La Vorágine, de José Eustásio Rivera. Estes exemplos reforçam, portanto, a construção espacial como importante elemento ficcional e ilustram que a espacialidade pode funcionar como uma alegoria capaz de inscrever a obra em determinadas perspectivas históricas e sociais.

Deste modo, propomos estabelecer um diálogo a partir dos sentidos alegóricos presentes na construção narrativa de dois espaços que funcionam como antagonistas: o Centro, em A Caverna, romance de José Saramago, e a Zona Franca, em A caligrafia de Deus, conto de Márcio Souza. Para esta reflexão de cunho bibliográfico, nos apoiaremos em Walter Benjamin (1984), em se tratando do conceito de alegoria; Maria Alzira Seixo (1987) acerca da crítica sobre Saramago, Tenório Telles (2013) no que concerne a crítica sobre Márcio Souza; Stuart Hall (2003) e Marc Augé (2012) para estabelecer um diálogo a partir das duas obras.

De acordo com Maria Alzira Seixo (1987) o procedimento de alegorização é uma das marcas fundamentais nas obras de Saramago e estendemos essa afirmação às narrativas de Márcio Souza, mas para que possamos assim afirmar é necessário que primeiro entendamos o conceito de alegoria. Walter Benjamin (1984) afirma que a alegoria passa a ter um novo lugar a partir do romantismo, que a reduziu ao torná-la uma forma de expressão responsável por refletir tipos de representações do mundo em que a obra se insere. A alegoria benjaminiana, deste modo, ocorre no movimento narrativo e não em um símbolo estanque colocado em uma palavra.

Em A caverna, romance publicado em 2000, a constituição alegórica representada pelo 
Centro provoca a tensão e o sofrimento de Cipriano Algor, que tem sua força de trabalho e seu meio de sustento inutilizados em um universo capitalista no qual o mercado dita as regras de aceitação e inserção do humano. A não marcação de pontuações na fala das personagens, por exemplo, pode ser lida como o que Stuart Hall (2003) denominaria de processo de construção da identidade na pós-modernidade. Neste processo as vozes se misturam e por vezes os diálogos são cíclicos, retirando o lugar de fala de determinados grupos sociais a partir do advento do capitalismo, representado no romance pelo espaço denominado Centro, antagonista que engole, marginaliza e corrompe as personagens.

O mesmo ocorre com o espaço representado no conto homônimo da coletânea $A$ caligrafia de Deus, do autor amazonense Márcio Souza, publicada em 1994, com narrativas ambientadas no cenário histórico do período de implantação do projeto da Zona Franca na cidade de Manaus. $\mathrm{O}$ conto aqui tratado apresenta personagens vítimas da marginalização social a partir do advento da Zona Franca, antagonista nessas narrativas, assim como o Centro, de A Caverna. Em A caligrafia de Deus, a promessa de um futuro promissor transforma-se em inutilidade da mão de obra de índios e ribeirinhos, "enquanto os poderosos se locupletam, o povo sucumbe de fome, miséria e desesperança nos bairros e favelas" (TELLES, 2013, p. 164). De forma análoga ao romance de Saramago, há diálogos cíclicos, a marginalização e a opressão das personagens, o que ocasiona, de acordo com Benjamin (1994), a ausência de perspectiva para resistir e relatar determinada perda social.

Dividiremos nossa leitura em três momentos: os dois primeiros trata-se de uma análise prévia das duas narrativas. Estas leituras contribuirão para que, no terceiro momento, possamos propor o diálogo dessas obras a partir dos espaços - Centro e Zona Franca - sob o prisma do antagônico, por compreendermos os sentidos alegóricos presentes nessas produções como veículos históricos que refletem os questionamentos da modernidade. "Nisso consiste o cerne da visão alegórica: a exposição barroca, mundana, da história como história mundial do sofrimento, significativa apenas nos episódios de declínio" (BENJAMIN, 1984, p. 188).

\section{A caverna, de José Saramago}

Para exemplificar nossa reflexão lancemos o olhar ao protagonista do romance, o oleiro Cipriano Algor, personagem que vive no campo a partir da produção e venda de louças de barro. Ainda no início da narrativa, Cipriano descobre que o Centro - espaço em que funciona o 
comércio da região - não está mais interessado em comprar suas louças, pois há uma novidade no mercado: louças de plástico. De maneira análoga ao mito platônico, o conflito de Cipriano Algor representa dois universos: o barro atua como figuração do universo de Cipriano e da personalidade construída a partir de suas vivências, representa o mundo do ser, da permanência, do campo; já o plástico simboliza o universo oposto, referente à modernidade, às aparências vividas pelo Centro. A partir dessa oposição nos debruçaremos sobre a narrativa, demarcando seus deslocamentos entre esses dois universos e a influência deles nas personagens.

A produção literária de Saramago, para Maria Alzira Seixo, apresenta uma arquitetura discursiva "bipolar", "mantendo como resultado uma tensão ideológica, ou a sua conversão através da ironia, da conclusão (ou abertura) claramente moralizante" (SEIXO, 1987, p. 18). Ainda em conformidade com Maria Alzira Seixo, observamos que as obras de Saramago são veículos históricos; o autor português se vale da literatura como uma ferramenta de reflexão do homem sobre si mesmo e seu lugar no mundo. Em A caverna, como veremos, essa reflexão está atrelada a uma série de questões próprias da modernidade, em que se torna onipresente o mundo dos objetos e a objetificação dos seres, abrindo espaço para o aumento da relevância social das imagens, dos simulacros e das simulações. Conforme Benjamin destaca: "Nisso consiste o cerne da visão alegórica: a exposição barroca, mundana, da história como história mundial do sofrimento, significativa apenas nos episódios de declínio" (BENJAMIN, 1984, p. 188).

Deste modo, Cipriano Algor pode ser visto como uma triste ilustração da inutilização da mão de obra no interior da dinâmica capitalista. No romance, quando Cipiano retorna para casa e decide contar para sua filha Marta sobre a recusa do Centro em comprar suas louças, a filha tem a ideia de que seu pai ofereça bonecos de barro para os compradores, bonecos que representem algumas profissões. Os dois selecionam seis modelos para reproduzi-los: o bobo, o palhaço, a enfermeira, o esquimó, o mandarim e o assírio de barbas.

\footnotetext{
Do que realmente aqui irá tratar, sem grandeza nem dramas, é de levar ao forno e cozer meia dúzia de estatuetas, insignificantes para que reproduzam, cada uma delas, duzentas suas insignificantes cópias, há quem diga que todos nascemos com o destino traçado, mas o que está à vista é que só alguns vieram a este mundo para fazerem adões e evas ou multiplicarem pães e peixes. (SARAMAGO, 2000, p. 173).
}

Após diversas tentativas em fazer os bonecos de barro, o oleiro apresenta o melhor resultado ao Centro. Um gerente muito chateado por Cipriano oferecer algo que não o solicitaram, aceita metade dos bonecos. Após esta metade, os compradores rejeitam 
completamente a proposta, fazendo com que Cipriano Algor perca as esperanças em continuar com seu trabalho como oleiro, trabalho este que alimentou gerações de sua família, sendo a única ocupação que o protagonista dominava. Podemos afirmar que a rejeição do Centro aos produtos do oleiro se insere no mecanismo significativo de uma tragédia alegórica que pode ser lida como a expressão do abandono e marginalização do homem diante do reinado das imagens e dos objetos na sociedade capitalista.

De acordo com Chauí (1997), as narrativas apresentam espaços intermediários entre os universos duplos. Por exemplo, há a espacialidade dupla - céu e inferno - da mitologia cristã e como espaço intermediário há o purgatório. O purgatório reforça as distinções entre o céu e o inferno, reafirma suas alegorias e funciona como uma fronteira capaz de intensificar o caráter cíclico da ambivalência da dupla espacialidade desta narrativa. Em A caverna, entre o campo, habitado por Cipriano Algor, e o Centro há uma estrada intermediária que serve de ambiente para diversas reflexões que reforçam a representação alegórica construída na narrativa. A moradia de Cipriano está localizada em um lugar preservado e pacífico, mas logo quando a personagem sai deste espaço, entra na "Cintura Verde":

\begin{abstract}
A região é fosca, suja, não merece que olhemos duas vezes. Alguém deu a estas enormes extensões de aparência nada campestre o nome técnico de Cintura Agrícola, e também por analogia poética de Cintura Verde, mas a única paisagem que os olhos conseguem alcançar nos dois lados da estrada, cobrindo sem solução de continuidade perceptível muitos milhares de hectares, são grandes armações de tecto plano, tectangulares, feitas de plástico de uma cor neutra que o tempo e as poeiras, aos poucos, foram desviando ao cinzento e ao pardo. Debaixo delas, fora dos olhares de quem passa, crescem plantas. (SARAMAGO, 2000, p. 12)
\end{abstract}

Após a passagem pela "Cintura Verde" há, antes de chegar ao Centro, a "Cintura Industrial", que assim como o espaço anterior é marcado por características que reforçam a proximidade com o Centro e seu antagonismo:

Deixaram a Cintura Agrícola para trás, a estrada, agora mais suja, atravessa a Cintura Industrial rompendo pelo meio de instalações fabris de todos os tamanhos, atividades e feitios, com depósitos esféricos e cilíndricos de combustível, estações eléctricas, redes de canalizações, condutas de ar, pontes suspensas, chaminés lançando para a atmosfera rolos de fumos tóxicos, gruas de longos braços, laboratórios químicos, refinarias de petróleo, cheiros fétidos, amargos ou adocicados (...) ninguém sabe o que se estará produzindo ali. (SARAMAGO, 2000, p. 13)

Para chegar ao Centro de forma mais rápida, o narrador afirma que Cipriano Algor e Marçal Gacho, seu genro, tomam um "traçado confuso" (SARAMAGO, 2000, p. 17). Esse trecho reafirma as demais passagens narrativas no interior da alegoria, entendida como uma 
construção ao mesmo tempo linguística, narrativa e cênica, visto que os espaços são descritos de forma detalhada e com uma carga imagética que reafirma a representação antagônica do Centro. Podemos esquematizar os seguintes espaços evidenciados a partir da dupla espacialidade Olaria-Centro:

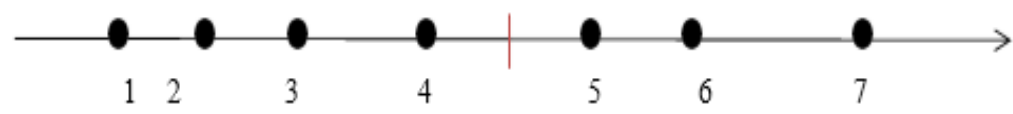

O espaço número 1 é a Olaria que representa o universo do ser como antes explicado, espaço de identificação de Cipriano Algor e sua família; os espaços número 2 e 3 são aqueles próximos à Olaria, respectivamente, o cemitério em que a esposa de Cipriano está enterrada, aonde ele vai uma vez por semana para refletir e conversar e (3) a casa de Isaura Estudiosa, por quem Cipriano nutre grande afeto. Esses ambientes são retratados como pertencentes ao universo da Olaria, ou seja, são espaços em que a narrativa não apresenta oposição à identidade social das personagens e sim um reforço à sua subjetividade. $\mathrm{O}$ espaço número 4 representa a Cintura Verde e marca o último espaço mais próximo ao universo da Olaria, lugar em que apesar da poluição ainda crescem plantas.

O eixo 5 representa a "Cintura Industrial", ponto em que a proximidade com o Centro começa a ser mais evidente devido às inúmeras fábricas, laboratórios e o estranhamento causado a partir delas: "ninguém sabe o que se estará produzindo ali" (SARAMAGO, 2000, p. 13). O eixo 6 representa o espaço da periferia, lugar onde há pessoas morando em barracas improvisadas nos encostamentos da estrada. Neste lugar há placas indicando que os motoristas devem parar; no entanto, o narrador afirma que Cipriano já sabe que essas placas foram feitas pelos próprios moradores, para que eles consigam roubar os caminhoneiros que por ali transitem. Esse espaço representa a marginalização ocasionada pelo eixo 7: o Centro.

Podemos apontar que a subjetividade de Cipriano Algor foi construída e reforçada a partir da Olaria. A família Algor se relacionava com a olaria como um espaço muito além de meio de subsistência. A olaria simbolizava a significação social de identidade e de reconhecimento. O trabalho como oleiro era um modo de subjetivação, um lastro para a existência familiar, já que a profissão era encarada como tradição: o avô de Cipriano foi oleiro, seu pai também o foi e o ensinou tudo que agora ele repassava à sua filha. Portanto, ainda que inserido no modelo salarial e na emergência de um capitalismo flexível, a 
linearidade produtiva dos Algor(es) simbolizava uma naturalização de um modo de vida e de uma subjetividade construída a partir disso.

Ao Cipriano vivenciar a expansão do processo de modernização a partir da industrialização e a substituição do seu trabalho artesanal ocorre uma opressão sobre seu modo de vida, sua subjetividade, identidade, lazer e espaço social. Essa opressão é representada pelo antagonista - Centro. O eu - Cipriano - é reprimido por este outro - o Centro - que não o enxerga como um indivíduo de voz ativa. Realiza-se, assim, a objetificação deste eu, tal como é ilustrado por uma das falas do protagonista Cipriano Algor quando começa a sentir essa força opressora: "pensei que não há grande diferença entre as coisas e as pessoas, têm sua vida, duram um tempo, e em poucos acabam, como tudo no mundo" (SARAMAGO, 2000, p. 62).

Para melhor expor nossa perspectiva, retomemos à narrativa: após a rejeição das louças e bonecos de barro fabricados por Cipriano, ele, sua filha e seu genro deixam a casa em que moravam e passam a residir no Centro, onde ocorre um movimento de agregação às normas de funcionamento. Marçal Gacho, genro de Cipriano, já estava habituado a esse espaço devido ao seu trabalho como guarda do Centro. Ele trabalhava por dez dias e tinha direito a 40 horas de folga para então recomeçar a carga horária de trabalho. Após a negativa das compras das louças e bonecos de barro feitos por Cipriano, Marçal é promovido a guarda residente, sendo indicado que ele deveria morar no Centro, nos apartamentos reservados para os funcionários e suas famílias que não poderiam ser numerosas e não poderiam ter animais. Após grande relutância por parte do oleiro, eles decidem se mudar e deixam Achado, o cachorro de estimação da família, com Isaura Estudiosa.

A atividade profissional de Marçal Gacho exemplifica mais uma modificação sofrida pelo trabalho no período moderno: a vinculação dessa atividade à ideia de coação social. De acordo com Freud (1974a), a coação social ocorre pelo fato de haver na modernidade a obrigatoriedade do trabalho como meio de sustento e de insercção a sociedade. Sob esse viés, em A caverna, o trabalho (sua forma) passa a ser coercitivo, pois não é mais possibilitado ao sujeito manter-se a partir do artesanato tradicional em sua família - as louças de barro. Deste modo, é imposto um modelo de trabalho que aprisiona o sujeito, tornando-o dependente, visto que somente por este modelo torna-se possível garantir a sua subsistência.

Após mudar de residência, Cipriano Algor observa que no Centro não há janelas e nem contato com o ambiente exterior. O Centro é caracterizado, deste modo, como uma espécie de 
shopping center no qual as pessoas residem e pagam altos preços para entrarem em salas nas quais simulam a sensação da luz solar, de um céu nublado ou de uma tempestade. A ausência de janelas sugere um ambiente de aprisionamento físico, um confinamento, ao mesmo tempo em que, simbolicamente, insinua o caráter de alienação e objetificação do sujeito.

Nesta parte do romance, Cipriano começa a buscar lugares obscuros que provavelmente estejam em partes não visitadas do Centro e assim ele encontra uma caverna com corpos já em decomposição e decide que, após aquela descoberta, não há como morar naquele lugar. Ao regressar para a Olaria, Cipriano se envolve afetivamente com Isaura e, após alguns dias, recebe a filha e o genro novamente, pois estes também perceberam o caráter devorador do Centro. Como forma de resistência à opressão do antagonista, há no desfecho da narrativa um movimento de retirada das personagens.

Cipriano, Marta, Marçal e Isaura Estudiosa, acompanhados do cão Achado, saem da cidade na furgoneta de Cipriano Algor e, ao passarem pela entrada do Centro, veem um cartaz e adivinham o que ele dizia: "Brevemente, abertura ao público da caverna de Platão, atracção exclusiva, única no mundo, compre já a sua entrada" (SARAMAGO, 2000, p. 350). Os dizeres do cartaz contido na entrada do Centro são a última frase do romance, o que reforça a construção alegórica - narrativa e cênica - arquitetada ao longo da obra, fechando o ciclo dos dois universos com a evasão do sujeito em busca de um novo espaço - físico e social.

\section{A caligrafia de Deus, de Márcio Souza}

A coletânea intitulada A caligrafia de Deus foi publicada pela primeira vez em 1994, contendo cinco contos. As narrativas são ambientadas no cenário histórico do período de implantação do projeto da Zona Franca em Manaus, a partir dos anos 1970. De acordo com Tenório Telles (2013), Márcio Souza foi contra a corrente de pessoas que aplaudiam e apoiavam o advento da Zona Franca em Manaus, criticando sua finalidade marginal. Em A expressão amazonense: do colonialismo ao neocolonialismo, Márcio Souza (1977) explica que a Zona Franca devoraria todos aqueles que não acompanhassem o que o projeto chamaria de integração. Os contos de A caligrafia de Deus relatam, justamente, histórias de personagens vítimas dessa marginalização social. Nos contextos apresentados em cada conto a esperança de um futuro promissor não se cumpre. A Zona Franca torna-se uma sugadora de vidas e sonhos. "Enquanto os poderosos se locupletam, o povo sucumbe de fome, miséria e desesperança nos bairros e favelas" (TELLES, 2013, p. 164). Sob esta perspectiva, propomos uma reflexão acerca 
do conto homônimo da coletânea para compreendermos a forma como o espaço Zona Franca se caracteriza de maneira antagônica, tal qual o Centro de A Caverna.

O conto começa com o trecho: "quarenta e oito horas depois, havia dois cadáveres atravessados por bala de fuzil" (SOUZA, 2007, p. 21). Trata-se do assassinato dos dois protagonistas, Izabel Pimentel e Alfredo Silva, este conhecido pelo apelido "Catarro”. Izabel era índia catequizada na cidade de São Gabriel da Cachoeira, pelas freiras Salesianas. Catarro havia sido criado como ribeirinho e agora tentava garantir sua subsistência a partir de práticas como a pirataria de fitas-cassete e outros pequenos delitos na cidade de Manaus. A narrativa é dividida em três episódios: "Introdução", "O primeiro cadáver" e "O outro cadáver". O tempo narrativo acontece in ultima res, no qual aos poucos o leitor é situado sobre os acontecimentos que ocasionaram o assassinato dos protagonistas.

O primeiro cadáver é encontrado com três balas alojadas na cabeça e caracterizado como alguém que "devia ter uns vinte anos, estava vestida só com uma calcinha rendada cor de limão. (...) como sairia nas matérias dos jornais (...) (SOUZA, 2007, p 23). O cadáver era de Izabel Pimentel, nascida em Iaureté-Cachoeira. A narrativa expõe que neste povoado os índios não são vistos como indivíduos, sofrem com o processo de destribalização, visto que não possuem o direito de um nome com origens indígenas. Ao contrário disso, todos os índios são registrados com o sobrenome Pimentel.

Todos em Iauareté-Cachoeira acabavam com o sobrenome de Pimentel. Izabel nascera em Iauareté-Cachoeira e não tinha escapado disso. Seu pai se chamava Pedro Pimentel e sua mãe, ao casar com ele, já trazia o nome de Maria Pimentel. Em IauaretéCachoeira isso até que podia provocar alguma confusão, pois não se podia levantar um mexerico de que a filha do Pimentel não era mais moça ou que o Pimentel colocava areia na pele de ucuquirana, sem que com isso toda a pequena cidade e inclusive a pessoa de onde tivesse partido o mexerico se comprometesse. Por isso não havia mexericos em Iauareté-Cachoeira, aliás, não havia nada de especial, nem mesmo uma cidade aquilo podia ser chamado, a não ser pela loucura dos habitantes de IauaretéCachoeira que enchiam a boca e diziam que eram da cidade de Iauareté-Cachoeira. (SOUZA, 2007, p. 23-24)

Salientamos que este trecho da narrativa dialoga com fatos históricos da colonização brasileira, já que no século XVIII, há a imposição do Marquês de Pombal à obrigatoriedade de um nome lusitano. No conto, Izabel era filha de um índio baniwa com uma índia tukano, mas segundo o narrador, não há nada em seus hábitos ou características que os diferenciem dos demais moradores de Iaureté-Cachoeira:

O pai de Izabel (...) passava o dia bebendo uma mistura de álcool com água e coçando os edemas que os bichos-de-pé provocavam em seus dedos sujos de terra. Mas nem 
isso podia ser considerado uma marca registrada do pai de Izabel, invariavelmente todos os homens de Iauareté-Cachoeira, assim como se chamavam Pimentel, passavam o dia bebendo álcool misturado com água e coçando os pés inchados de bichos. Uma outra diversão do velho Pedro era espancar a mãe de Izabel duas vezes por ano. Uma no Natal e outra no dia de Nossa Senhora Auxiliadora. A mãe de Izabel, uma índia tukano, tinha alguns dedos inutilizados devido a essa prática anual do marido. (...) É claro que os dedos inutilizados da mãe de Izabel não serviam para identificá-la: todas as mulheres casadas apanhavam dos maridos nas mesmas datas e tinham igualmente os dedos inutilizados que mostravam para as filhas, como uma advertência, todas as vezes que elas vinham falar de casamento. (SOUZA, 2007, p. 24-25)

Izabel, assim como as outras índias adolescentes, estudava e era catequizada na cidade de São Gabriel da Cachoeira pela chamada "Missão dos Salesianos", sua relação com as freiras e o padre da Missão sempre fora ambígua, sendo constantemente influenciada por eles. O maior sonho de Izabel era beijar na boca, desejo que alimentava a partir da leitura de revistas da moda que chegavam na escola através de algumas meninas que tinham parentes em Manaus. Madre Lúcia, freira do colégio Salesiano, convence Izabel de que seus dentes são desalinhados e amarelos, sendo apenas uma prótese dentária com dentes alvos e alinhados capaz de fazer dela uma perfeita moça da cidade, ou seja, dentes alvos e alinhados dariam a Izabel um status de modernidade e a fariam realizar seu sonho de beijar na boca.

\begin{abstract}
Madre Lúcia havia dito que com isso ela podia ficar uma perfeita moça da cidade, com um sorriso parecido com os das moças das revistas de fotonovelas. Izabel Pimentel queria saber qual a sensação de um beijo com aqueles dentes maravilhosos e que ela poderia tirar e pôr a hora que bem entendesse. Ela poderia beijar com dentes, beijar sem dentes, e por isso estava achando aquilo uma loucura. (...) Chegou à conclusão que só por loucura alguém podia chamar de dentes aquelas presas que ela tinha na boca. Na outra manhã, para alegria de Madre Lúcia, ela deu início ao processo de transformar sua boca de bugre em boca de gente. Cada dente extraído, daí para frente, era como se deixar levar mais uma vez pela exótica maneira de Deus riscar no mundo a sua sina. Mas o processo não era barato, não seria feito de graça. Madre Lúcia agora dava as tarefas mais duras na roça para Izabel Pimentel fazer. O piso de cimento da Igreja lavado, a poeira dos livros dispersada e as roupas engomadas pela mão de Izabel, para que ela tivesse lindos dentes na caverna flácida em que sua boca se transformava. Izabel era uma menina dura quando perseguia algum desejo e agora, enquanto se ocupava dos muitos afazeres da Missão, divertia-se em cuspir no chão aquelas marcas de sangue que lhe deixavam um gosto salgado descendo pela garganta. (SOUZA, 2007, p. 31-32)
\end{abstract}

A partir dessa influência, Izabel encara a mutilação como parte da normalidade de seu cotidiano e arranca todos os dentes. A perda dos dentes de Izabel reforça o sentido alegórico da perda da força, da extirpação de um elemento físico que poderia servir de defesa também, simbolicamente levando a personagem a estar sob a dominação do missionário e colonizador, antes colocando um sobrenome lusitano e agora impondo ou limitando suas características físicas a partir de mutilações. 
Pedro Pimentel, pai de Izabel, falece devido a um edema causado por um bicho-de-pé e as freiras da "Missão Salesiana" oram por sua alma a contragosto. Há então a surpresa de que “(...) no primeiro Natal em que a mãe de Izabel Pimentel passaria sem espancamentos, Madre Lúcia cometeu a suprema loucura de obrigar um C-47 inteiro da FAB a transportar (...) um par de próteses dentárias para ela" (SOUZA, 2007, p. 34). O resultado é a rejeição: nenhum rapaz de Iauaretê-Cachoeira deseja beijar uma boca como a de Izabel, com dentes tão alvos e descartados a qualquer momento. Desiludida, Izabel resolve partir no mesmo C-47 da FAB, rumo a um emprego proposto pela Madre Lúcia em Manaus, no Colégio Salesiano. Mais uma vez a imposição da freira dita o destino da personagem:

A transformação física violenta é a única regra possível para esta personagem, a única alternativa restante para quem deseja sobreviver num mundo amazônico, onde a religião dita as regras. Estas personagens são estranhas para si mesmas, suas identidades são perdidas, isto é, arrancadas no caminho ou melhor dito: forjadas (SANTELLI, 2008, p. 1).

O outro cadáver é descrito como: "Alfredo Silva, vinte e cinco anos, corpo bem proporcionado para a pouca estatura, medroso e astuto, (...) estava morto e chegou a essa situação depois de compreender que tinham todos enlouquecido em Manaus (SOUZA, 2007, p. 35-36). Alfredo da Silva cresceu como ribeirinho e fora apelidado de Catarro logo que começou a fazer pequenos furtos na capital do Amazonas. Nesta parte do conto é narrado como Izabel e Catarro se conheceram. Izabel foi apelidada, em Manaus, como "Índia potira" e trabalhava no prostíbulo $O$ Selvagem, “o mais animado e turbulento dos prostíbulos e santuário máximo da vida noturna da Zona Franca das Cem Mil Putas. Ela parecia louca mesmo e acabou fazendo dele o seu xodó” (SOUZA, 2007, p. 42).

Izabel começara a trabalhar no prostíbulo por ter fugido da Escola Salesiana e não ter se habituado a trabalhar em um emprego que conseguiu em uma empresa da Zona Franca, na fábrica de fitas cassete Sayonara Eletrônica, devido a extensiva carga horária de trabalho e os meios desumanos com os quais os funcionários eram tratados pela empresa. Além disso, o sonho de Izabel de beijar na boca não se realizaria até a sua morte, já que como prostituta, os homens continuavam rejeitando a ideia de beijá-la.

Catarro viera para Manaus por não se adaptar à vida como ribeirinho. “Todos os anos o rio começava a encher e invadia tudo e eles eram obrigados a ir suspendendo o piso da casa e pondo os bichos em marombas para que não morressem afogados" (SOUZA, 2007, p. 45). Em 
Manaus, Catarro vendia fitas com vídeos pornográficos, era carregador de bananas e caixas de laranjas. A maneira como Catarro conseguia adquirir os vídeos para vender era ilegal e foi assim que ele conheceu o Comissário Frota, policial que diversas vezes tentou encontrar indícios para ser violento contra Alfredo da Silva. Diferente da representação das personagens de A Caverna, de Saramago, o Comissário Frota constitui uma personagem que, de certa forma, incorpora a violência ocasionada pela Zona Franca e pelo poder estatal.

(...) Comissário Frota, o sacana que já o tinha pendurado tantas vezes no pau-de-arara e que gostava de colocar gelo em seu saco, mesmo quando ele já tinha dado o serviço. O Comissário Frota era um louco, pensava Catarro, um homem franzino mas muito aborrecido, impetuoso e cruel quando cercado de outros tiras e procedia a algum interrogatório, complacente quando aparecia algum advogado ou quando era obrigado a se envolver em problemas com filhos de família. Mas nos encontros do Comissário Frota e Catarro, o desgraçado do tira sempre tinha sido inflexível ao absoluto. O Comissário Frota chegara à conclusão, tirada do fundo de sua experiência policial, que poderia solucionar todos os problemas de latrocínio em Manaus pela prisão e muita porrada no lombo de Catarro. E essa certeza já estava ficando incômoda para Catarro, porque não havia crime ou assalto que acontecesse na cidade que ele não fosse imediatamente capturado, seviciado e, sem mais outras explicações, libertado, porque o Comissário Frota era incapaz de resolver o menor problema de roubo de galinhas. Até o apelido de Catarro, que tanto o irritava, tinha sido consagrado pelo Comissário Frota nas diversas entrevistas que ele dava diariamente à imprensa. E na loucura da Zona Franca, a única editoria de jornal que realmente funcionava era a editoria de polícia. (SOUZA, 2007, p. 36-37)

Em um patrulhamento policial comandado pelo Comissário Frota que Catarro é assassinado, no que os policiais nomeiam como Operação Grande Zona, que consistia em prender alguns criminosos procurados pela cidade de Manaus. O primeiro cadáver, o corpo de Izabel, também foi enquadrado como uma das pessoas suspeitas de envolvimento criminoso. Quando encontrado, Catarro estava bebendo em um bar e apesar de não ter deitado no chão como o Comissário pedia, não reagiu. Ainda assim, foi assassinado e acusado de diversos crimes que jamais havia cometido e sem ao menos ter conhecimento sobre estas acusações.

Tenório Telles (2013) salienta que mesmo que as personagens não fossem mortas pelo contexto urbano que aparentemente as aceitaria, estariam, como antes, marginalizadas. $\mathrm{Na}$ narrativa, o reforço desta marginalização ocorre justamente através da representação do Estado pelo Comissário Frota, com uma visão distorcida e preconceituosa. Deste modo, Izabel e Catarro tornam-se, a partir da indiferença do Estado, "protagonistas que evocam o destino de milhares de homens e mulheres que foram deserdados do paraíso capitalista” (TELLES, 2013, p. 169).

Há na representatividade do Comissário Frota um caráter coercitivo somado ao sentido alegórico da organização panóptica da sociedade, fundamental no estabelecimento do modelo 
industrial. Michel Foucault (1987), salienta que a organização panóptica retrata uma prisão modelar, na qual os prisioneiros eram dispostos em celas individuais e em círculo ao redor de uma torre central que, com base em um cálculo de abertura das janelas, as posicionavam em um regime de visibilidade. Deste modo, todos os prisioneiros estavam visíveis àquele que os vigiasse, entretanto, este movimento não era recíproco. Diante da onipresença da torre central, com vigias protegidos por biombos e persianas, tinha-se apenas a impressão permanente de ser vigiado. Foucault (1987) explica que muito além de ser uma estratégia arquitetônica inserida no regime prisional, a organização panóptica constitui um dos traços característicos da sociedade disciplinar, o que em nossa leitura de A caligrafia de Deus acontece a partir da delegação de poderes a instituições disciplinadoras representadas pela Zona Franca e incorporadas pelo Comissário Frota.

Sob esta perspectiva, o panoptismo é a forma de poder que atua sobre o sujeito a partir da vigilância individual e ininterrupta. Há, assim, uma espécie de método de punição sob o aspecto de correção o que ocasiona a formação dos indivíduos de acordo com certas normas. As ações violentas e autoritárias do Comissário Frota compõem, deste modo, o que Foucault (1987) denomina como a tríplice da organização panóptica - vigilância, controle e correção o que representa uma forte característica das relações de poder presentes nas sociedades modernas. O conto termina por ilustrar que estas relações de poder condicionam os indivíduos que vigiam a reconhecerem-se como altamente poderosos a partir do controle sobre o outro, alienando-os como marionetes da sociedade disciplinar:

O Comissário Frota estava certo de que operações como aquela poderiam bem ser repetidas uma vez por ano, para dar um pouco de movimento à rotina da Polícia. $\mathrm{O}$ repórter parecia um índio desenhado a crayon, a boca sarcástica e os olhos amarelos sem nenhuma esperança de inteligência. Era o repórter policial mais brilhante de Manaus e escrevia verdadeiros editoriais na página de polícia, lamentando a falta de meios com que os policiais trabalhavam e a benevolência com que a Justiça parecia aquinhoar os meliantes, liberando ladrões e assassinos por meio de abomináveis habeas-corpus. Quem lia aqueles artigos ficava pensando que o autor era um cara que gostava de brigar e que por isso mesmo era um rematado idiota. O Comissário Frota se esforçava para ganhar uma expressão horrível de cansaço, mas ficava cada vez melhor e mais saudável, o suor secando com a brisa que sacudia o mamoeiro onde um praça da PM estava tentando derrubar um mamão maduro todo picado pelos sanhaçus. O repórter queria saber se os bandidos não teriam alguma ligação com o narcotráfico e ouviu o Comissário Frota resmungar, contrariado, que eram dois cretinos que nunca seriam aceitos nem mesmo como mulas pelo mais idiota dos colombianos. (SOUZA, 2007, p.46-47)

Sob este aspecto, os discursos daqueles que estão à margem são contrapostos ao midiático, devido falsas informações das representações estatais que, por retirarem o lugar de 
fala dos que estão marginalizados, tornam-se verdade absoluta. Esta opressão mina a subjetividade dos indivíduos, no conto representados por Izabel e Catarro. Logo, a "mercantilização nega a memória porque a operação própria de toda nova mercadoria é substituir a mercadoria anterior. (...) A literatura pós-ditatorial testemunharia, então, esta vontade de reminiscência, (...) do passado entendido como catástrofe" (AVELAR, 2003, p. 238).

\section{Alegoria e modernidade: o Centro e a Zona Franca como não-lugares}

De acordo com Maria Alzira Seixo (1987) o procedimento de alegorização é uma das marcas fundamentais nas obras de Saramago e propomos aqui estender esta afirmação ao conto de Márcio Souza. Sob a perspectiva aqui abordada, em A caverna a alegorização se dá em contato e contraste ao conhecido mito platônico, numa possível atualização desse mito para o âmbito da modernidade. Em A Caligrafia de Deus o procedimento de alegorização acontece sob o aspecto da marginalização ocasionada a partir do que era dado como um projeto de modernização - a Zona Franca - que desenvolve uma organização panoptíca que oprime índios e ribeirinhos. Walter Benjamin (1984) afirma que a alegoria passa a ter um novo sentido a partir do romantismo, que a tomou como uma forma de expressão responsável por encapsular representações do mundo em formas figurais que se desenvolvem narrativamente. Com isso a alegoria redimensiona num todo maior o sentido do movimento histórico em que se dá a construção de determinado discurso. Como uma forma específica de expressão, a alegoria para Benjamin (1984) se relaciona dialeticamente com o conceito de símbolo: compreende forma e conteúdo, elementos sensíveis e ideias inconscientes partilhadas pela sociedade. A alegoria benjaminiana, no entanto, se desenvolve no movimento narrativo de significação e recolhimento dessa siginificação numa figura representativa, e sua dinâmica pode servir como ilustração da espacialidade narrativa.

O mecanismo significativo da dinâmica alegórica nos possibilita fazer uma leitura de A Caverna, bem como de A Caligrafia de Deus, como narrativas que retratam o caráter social de seu tempo. Sob este viés, concebemos a tensão e o sofrimento de Cipriano Algor, assim como o assassinato de Izabel e Catarro como seres marginalizados, cuja força de trabalho e seu meio de sustento são inutilizados no interior da dinâmica capitalista, na qual o mercado dita as regras de aceitação e inserção do humano no que Baudrillard (1988) chama de sistema de objetos. Podemos assim afirmar que José Saramago e Márcio Souza se valem dos recursos 
da escrita para a construção significativa de uma representação alegórica. A não marcação de pontuações na fala das personagens nas duas narrativas, por exemplo, pode ser lida como signo do que Stuart Hall (2003) denomina como processo de construção da identidade na pós-modernidade, visto que as vozes se misturam e por vezes os diálogos são cíclicos, fazendo com que diferentes personagens expressem os mesmos pontos de vista, demarcando uma espécie de homogeneização linguística no interior da dinâmica capitalista, representada então pela figura do Centro e da Zona Franca, antagonistas que engolem, marginalizam e corrompem suas respectivas personagens.

De acordo com Benjamin (1984, p. 214) "a alegoria manifesta-se tanto no elemento linguístico como no figural e no cênico”. Deste modo, as narrativas de Saramago e de Souza podem ser lidas, ainda, como um reforço à multiplicação de sentidos conflituosos, através da tensão dialética entre um ideal social humanístico - o homem como um ser realizado que é ouvido e compreendido - e a consciência da impossibilidade de escapar deste universo contemporâneo de imagens e representações, que para Baudrillard (1988) são um sistema ilusório de alienação social, que nivela os humanos a animais e, neste sentido, também termina por dar características humanas aos animais.

Talvez por isso, em alguns momentos da narrativa de A caverna, o cão Achado toma a palavra e faz ponderações reflexivas, por exemplo, quando Cipriano e sua filha estão retirando do forno alguns bonecos de barro e o cão tenta brincar com eles sendo severamente impedido por quase ter feito o material cair: “o cão Achado só daqui a pouco reparará que os donos levam umas figuras de barro em equilíbrio sobre umas tábuas, (...) imagina-se o desastre que sucederia se não me tivessem travado a tempo às efusões" (SARAMAGO, 2000, p. 181) (grifo nosso). Ademais, esta mesma tensão desenvolvida a partir desses sentidos alegóricos explica o pensamento de Cipriano Algor ao igualar-se às coisas, objetificando-se: "pensei que não há grande diferença entre as coisas e as pessoas, têm sua vida, duram um tempo, e em poucos acabam, como tudo no mundo" (SARAMAGO, 2000, p. 62).

Sob essa perspectiva, os sentidos alegóricos desenvolvidos em cada narrativa constroem um arquétipo comum ao Centro, em A Caverna, e à Zona Franca, em A Caligrafia de Deus: ambos funcionam como não lugares. Marc Augé (2012) explica que na modernidade há a constituição de lugares: espaços que formam o sujeito em sua identidade, com relações subjetivas e históricas, sendo estas em sentido antropológico: espaço e tempo personalizados e comuns a uma comunidade (AUGÉ, 2012, p. 73). O autor explica que a partir dessas relações históricas há a criação de "lugares da memória", ou seja, lugares que rementem a uma memória 
coletiva formando aspectos de sua identidade e cultura. Sob esse viés, um espaço que não é identitário, nem relacional e nem histórico para a formação do indivíduo, não ampara nenhuma sociedade orgânica, marginalizando diversos grupos sociais. Em conformidade com Augé (2012), o não lugar é amplamente oposto ao lar, ao que seria um espaço de origem e de conforto, ou seja, o não lugar é um espaço que objetifica os seres, retirando sua individualidade e suas referências enquanto sociedade.

Espaços como aeroportos, grandes clínicias hospitalares, redes de supermercado ou restaurantes uniformizados pelo mundo inteiro além do trânsito das metrópoles e cadeias de hotéis, são espaços em que a singularidade é nula. Nestes espaços somos identificados apenas como clientes ou trabalhadores, papeis que podem ser desenvolvidos por qualquer outro indivíduo sem expressar nenhuma preferência ou característica cultural. Augé (2012) explica, ainda, que os não lugares são o maior produto da organização industrial, organização esta que acaba por minar a formação subjetiva do sujeito, espacial e linguisticamente. Os não lugares criam, deste modo, uma espécie de glossário comum a todos, uniformizando até o modo de comunicação dos indivíduos, palavras como check-up, fast-food, coffee break, check-in e respostas rápidas sobre a forma de pagamento de uma compra, por exemplo, são as únicas trocas linguísticas realizadas nos não lugares em todo o mundo. Estes espaços, portanto, não são habitáveis porque não aceitam aqueles que não estejam uniformizados ao parâmetro capitalista que classifica os indíviduos como mão de obra e/ou consumidor.

De acordo com o conceito exposto, ao retornarmos à linha que ilustra os lugares de identificação de Cipriano Algor e sua família, podemos afirmar que não apenas o Centro eixo 7 - constitui um não lugar, como também a Cintura Industrial e periferia próxima ao Centro (eixos 5 e 6$)$ :

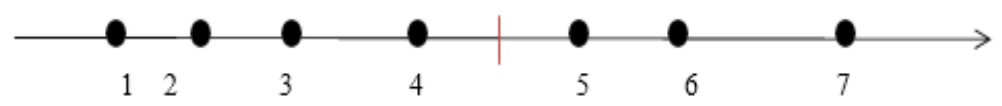

Assim, a mudança de Cipriano, sua filha e seu genro para o Centro representava o abandono da tradição, a quebra com os laços parentais e sua identificação histórica construída ao longo de gerações a partir do lugar Olaria: “(...) tudo ali estava coberto de barro, não sujo de barro, somente da cor que ele tem, (...) o que foi sendo deixado por três gerações que todos os dias mancharam as mãos no pó e na água do barro (...)" (SARAMAGO, 2000, p. 35). Deste modo, a mudança para um não lugar como o Centro, representa uma tragédia alegórica a partir 
da angústia perante a vida do sujeito que se vê desterritorializado de suas referências subjetivas. Esse sofrimento é exposto a partir de alguns pensamentos de Cipriano Algor:

(...) é o trabalho que deixou de ser o que havia sido, e nós, que só podemos ser o que fomos, de repente percebemos que já não somos necessários no mundo, se é que alguma vez o tínhamos sido antes, mas acreditar que o éramos parecia bastante, parecia suficiente, e era de certa maneira eterno pelo tempo que a vida durasse, que é isso a eternidade, nada mais do que isso. (SARAMAGO, 2000, p. 106)

De acordo com Freud (1974), aquilo que reforça a subjetividade do sujeito pode ser lido como pulsão de vida, enquanto o seu silenciamento a partir de opressões externas ou internas, e os mecanismos advindos deste silenciamento, seria denominado pulsão de morte. Deste modo, em nossa leitura, os espaços intermediários entre a Olaria e o Centro representam as mudanças sofridas pelo sujeito a partir da organização industrial própria dos não lugares da modernidade. Fazendo, portanto, com que a Olaria esteja para a (pulsão de) vida enquanto o Centro representa a (pulsão de) morte para a subjetividade de Cipriano Algor.

Em contraponto, a opressão vivenciada por Izabel e Catarro, em A Caligrafia de Deus, é vivenciada desde os espaços em que eles nasceram. Seguindo o raciocínio de Augé (2012), diríamos que esses espaços não realizam identificações sólidas, visto que Izabel era constantemente tolhida pela Escola Salesiana e Catarro sentia-se frustrado pelas condições em que vivia como ribeirinho. Estes espaços estão, portanto, horizontalmente ligados à Zona Franca, o que poderíamos ilustrar da seguinte maneira:

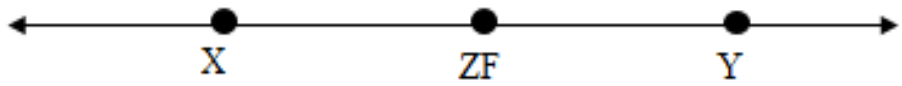

Assim, Iaureté-Cachoeira e a Escola Salesiana, espaços onde Izabel cresceu e foi catequizada estão representados por X, ligados a Zona Franca (ZF) que também é relacionada diretamente com o espaço (Y) em que Catarro cresceu como ribeirinho. Essa ligação acontece devido o conto expor que tanto Izabel quanto Catarro foram levados a sair de seus espaços de origem em tentativas de resistência à opressão vivenciada por eles para serem lançados à Zona Franca, antagonista que os oprimiu até a morte. Há, deste modo, um processo caracterizado por Stuart Hall (2003) como perda da identidade cultural, representado neste caso por Izabel e Catarro, visto que a vivência nesses não lugares nega o que Augé (2012) denomina como lugares da memória, ou seja, espaços físicos que constituam uma memória coletiva que possibilite a formação da identidade e cultura dos sujeitos. O conto de Márcio 
Souza conota, assim, a vivência do luto da memória dos habitantes da Amazônia, antes massacrada pelos colonizadores europeus e depois marginalizada com o advento da Zona Franca, pois, de acordo com Oliveira (2003), para que haja uma recuperação da identidade antes oprimida, seria necessário que houvesse a recuperação da memória.

Em outras palavras, o que denominamos como vivência do luto da memória é um processo realizado pela própria produção de Márcio Souza, pois, é apenas a partir da vivência deste luto que se torna possível a preservação da memória de tudo o que antes buscava-se olvidar, silenciar e destruir da identidade individual e coletiva. "O luto, de modo geral, é a reação à perda de um ente querido, à perda de alguma abstração que ocupou o lugar de um ente querido, como o país, a liberdade ou o ideal de alguém (...).” (FREUD, 1974, p. 275). Freud (1974) aponta, ainda, que a vivência do luto se realiza através de estágios psíquicos a partir da negação do fato propulsor do próprio luto, indo à melancolia ou à revolta, até completar-se em uma elaboração das reações suscitadas pela perda que, quando vivenciada corretamente, desaguará na aceitação. Essa aceitação não é em si do ocorrido, da violência e da perda vivenciadas, por exemplo, mas do inegável fato de um sinistro ter ocorrido. Assim, através da memória é compreendido que o fato propulsor do luto permanece como real, naturalmente não para voltar ao presente, o que seria patológico, mas para, por meio da memória elaborada, impedir que haja a possibilidade de retorno à violência representada. A narrativa, portanto, caminha para a elaboração do luto da memória de índios e caboclos ao instruir o sujeito a um processo de sucessivas ressignificações identitárias a partir do assassinato alegórico de Izabel e Catarro pelo contexto antagônico da Zona Franca.

\section{Considerações finais}

Neste texto objetivamos empreender uma reflexão sobre como certas dimensões espaciais constituídas em narrativas de José Saramago e Márcio Souza revelam seu caráter alegórico como componente crítico de ambos os autores frente às problemáticas contemporâneas. Tal sentido se expressa na esteira do que Walter Benjamin reportou como princípios fundamentais da alegoria na modernidade, isto é, seu revestimento narrativo e sua capacidade de representar o declínio do humano diante da brutalização imposta pelos regimes de produção que reificam os sujeitos.

Os textos convergem também pela escolha de narrar a história a partir dos marginalizados. Na perspectiva de Saramago, o olhar para aqueles que não se adaptam ou não 
serão adaptados pelo sistema. Na perspectiva de Souza, a narrativa sobre vidas cujas biografias planificadas nas páginas policiais ganham na ficção do autor uma memória minimamente forjada na experiência dos deserdados.

Salientamos que, apesar das convergências apontadas, as duas narrativas apresentam contrastes. É o que se verifica, por exemplo, em termos parciais, na relação entre funcionalidade e nomeação. No Centro, em A caverna, não há personagens nomeadas ou que apareçam com frequência para representar a opressão deste espaço. As personagens são caracterizadas por suas profissões, há o gerente que informa que o Centro não tem mais a necessidade contratual em comprar as louças de Cipriano Algor. O chefe e os colegas de Marçal Gacho e os trabalhadores que recebem Cipriano quando este começa a residir no Centro, por exemplo. Em A caligrafia de Deus, no entanto, o Comissário Frota incorpora a voz opressora da Zona Franca, sendo um agente para que as normas impostas a partir desse espaço estatal sejam cumpridas. Marc Augé (2012) explicaria que, nesse caso, ainda que as pessoas que desenvolvam funções específicas sejam tratadas a partir de seus nomes e acreditem que desempenham certa singularidade, sua função nesses espaços pode ser desenvolvida por qualquer outro indivíduo com o mesmo treinamento, ou ainda, por máquinas e robôs. Neste caso, o Comissário Frota poderia representar na organização panóptica proposta pela sociedade industrial, como antes refletimos, qualquer indivíduo que vigia e que por isso não seria mais do que uma marionete da organização industrial.

De modo geral, a análise da representação antagônica dos espaços ora descritos mostra como o problema da identidade está no cerne da questão, pois tais espaços vão se constituindo de modo a forçar os sujeitos a se dirigirem progressivamente para um apagamento de si e uma mercantilização das relações que outrora negariam a lógica produtiva do capital.

Por fim, deixamos registrado que o potencial de análise das duas principais categorias narrativas aqui tratadas não se esgota, pois tanto a alegoria como o espaço, nas obras dos autores aqui enfocados, estão relacionadas com outras estruturas, como o mito, a história, a linguagem e a cultura, relações as quais poderão ser exploradas em leituras vindouras.

\section{Referências}

AVELAR, Idelber. Alegorias da derrota: a ficção pós-ditatorial e o trabalho do luto na América Latina. Trad. Saulo Gouveia. Belo Horizonte: Editora UFMG, 2003.

AUGÉ, Marc. Não lugares: introdução a uma antropologia da supermodernidade. Trad. Maria 
Lúcia Pereira. 9 ed. Campinas, São Paulo: Papirus, 2012.

BAUDRILLARD, Jean. El outro por sí mismo. Trad. Joaquín Jordá. Barcelona, Espanha: Anagrama, 1988.

BENJAMIN, Walter. Experiência e pobreza. In: Magia e técnica, arte e politica: ensaios sobre literatura e história da cultura. Trad. Sérgio Paulo Rouanet. 7 ed. São Paulo: Brasiliense, 1994.

O autor como produtor. In: Magia e técnica, arte e política: ensaios sobre literatura e história da cultura. Trad. Sérgio Paulo Rouanet. 7 ed. São Paulo: Brasiliense, 1994a.

O narrador. Considerações sobre a obra de Nikolai Leskov. In: Magia e técnica, arte e política: ensaios sobre literatura e história da cultura. Trad. Sérgio Paulo Rouanet. 7 ed. São Paulo: Brasiliense, 1994b. 1984.

Origem do drama barroco alemão. Trad.: Sérgio Paulo Rouanet. São Paulo: Brasiliense,

CHAUÍ, Marilena. Convite à filosofia. São Paulo: Ática, 2000. Disponível em: https://edisciplinas.usp.br/pluginfile.php/1936981/mod_resource/content/3/aula\%201_CHA U\%C3\%8D\%2C\%20Marilena.\%20Convite\%20\%C3\%A0\%20Filosofia.pdf. Acesso em: Manaus, 18 de junhi de 2019.

FREUD, Sigmund. Luto e melancolia (1917 [1915]). In: Edição Standard Brasileira das obras Psicológicas Completas de Sigmund Freud. Volume XIV (1914-1916). Rio de Janeiro: Imago Editora LTDA, 1974.

O mal-estar da civilização (1974 [1930]. In: Edição Standard Brasileira das obras Psicológicas Completas de Sigmund Freud. Volume XIII (1927-1931). Rio de Janeiro: Imago Editora LTDA, 1974a.

FOUCAULT, Michel. Vigiar e punir. Trad. Raquel Ramalhete. 27 ed. Petrópolis: Vozes, 1987.

HALL, Stuart. A questão multicultural. In: Da diáspora: identidade e mediações culturais. Belo Horizonte: Editora UFMG, 2003.

OLIVEIRA, José Ademir de. Manaus de 1920-1067: a cidade doce e dura em excesso. Manaus: Valer; Governo do Estado do Amazonas; Edua, 2003.

SANTELLI, Adriana Delgado. As estações da Caligrafia de Deus. [S.1.: s.n.]. 2008. Disponível em: $<<$ http://www.ufac.br/portal/unidades-administrativas/orgaoscomplementares/edufac/revistas-eletronicas/revista-seringal-de-ideias/edicoes/edicao-012008/artigos/as-estacoes-da-caligrafia-de-deus > Acesso em: Manaus, 18 de junho de 2019.

SARAMAGO, José. A caverna. São Paulo: Cia das Letras, 2000.

SEIXO, Maria Alzira. O essencial sobre José Saramago. Lisboa: Imprensa Nacional; Casa da Moeda, 1987.

SOUZA, Márcio. A caligrafia de Deus. São Paulo: Lazuli; Companhia Editora Nacional, 2007. 

1977.

Expressão amazonense: do colonialismo ao neocolonialismo. São Paulo: Alfa-Ômega,

TELLES, Tenório. A caligrafia de Deus: ilusão e tragédia nos trópicos. In: LEÃO, Allison; KRÜGER, Marcos Frederico (orgs.). O mostrador da derrota: estudos sobre o teatro e a ficção de Márcio Souza. Manaus, AM: UEA Edições, 2013.

Recebido em 28 de novembro de 2019 Aceito em 01 de março de 2020 